\title{
Product Lifecycle Management and Sustainable Development in the Context of Industry 4.0: A Systematic Literature Review
}

\author{
Michele MARCOS DE OLIVEIRA ${ }^{\mathrm{a}}$, Luisa GERALDI ANDREATTA ${ }^{\mathrm{a}}$, \\ Josip STJEPANDIĆ ${ }^{\mathrm{b}}$, Osiris CANCIGLIERI JUNIOR ${ }^{\mathrm{a}}$ \\ andustrial and Systems Engineering Graduate Program, Pontifical Catholic \\ University of Paraná, Curitiba - Paraná, Brazil \\ b PROSTEP AG, Darmstadt, Germany
}

\begin{abstract}
The Fourth Industrial Revolution and its disruptive technologies are emerging massively. With various motivations for its implementation such as elevation of speed, reducing costs, mitigating errors, and other different factors, more and more technology are being employed to solve business problems and increase profit. Through the years, product lifecycles have been shorted as a good reason to reduce production costs and give to consumers the experience of replacing goods in shorter periods. This linear cycle of "produce-use-dispose" reached a massive success in the last decades, but have started to show lack of sustainability for consumer and industry. This work aims to conduct a Systematic Literature Review about the future challenges for Product Lifecycle Management and Sustainable Development, considering the context of Industry 4.0. The expected outcome for this study is to find elements that can support the use of 4.0 technologies in Product Lifecycle Management with a strong background for Sustainable Development.
\end{abstract}

Keywords. Product Lifecycle Management, PLM, Industry 4.0, 4th Industrial Revolution, Sustainable Development, Sustainability, Transdisciplinary.

\section{Introduction}

The Fourth Industrial Revolution and its disruptive technologies are emerging massively. Everyday refinement of software, equipments, new applications, and performance record is becoming a reality for various enterprise profiles: from small business, start-ups to large multinational industries, every enterprise has been looking for technology to accelerate the main lesson from the classic production concepts: do more with less effort [1].

With various motivations such as elevation of speed, reducing costs, mitigating errors, and other different factors, more and more technology are being employed to solve business problems, generate innovation and increase profit [1][2]. Financial sustainability is the primary justification for all these outcomes, for which an organisation would not need to face economic challenges or if the desire to enlarge its profitability. It seems that technology has been supporting companies to reach these financial goals, and this objective solely would justify the investment [3].

However, through the years, product lifecycles have been shorted as a good reason to reduce production costs and give consumers the experience of replacing goods in shorter periods. This linear cycle of "produce-use-dispose" had its massive success in the 
last two centuries [4][5]. Following this manufactures productivity demand, it is possible to realise changes in the consumer's behaviour contributing to the growth of the contemporary global problems such as pollution, wasting, economic disparities among other negative effects [3].

Thankfully to the broad availability of information, consumers are more conscious about their choices, which means that scrutinising a product has increased considerably. Further, digitisation motivates consumers to access innovations such as sharing economy [6]. Some manufacturers have then adopted green initiatives and sustainable approaches to reach more consumers, especially to compete in international markets [7] [3].

Other elements that corroborate the need for a shift for this company's profiles are technology adoption. Historically, technologies helped society development, productivity and economy. However, the speed of technological spreading in the last industrial revolutions are incomparable to the exponential proportions that the Fourth Industrial Revolution has already reached [8].

There are several initiatives to adopt 4.0 Industry: elements such as real-time data collection for the decision have been a good application in IT-enable PLM manufactures to foster cleaner production and achieve sustainable development [9] [10].

Moreover, climate change induced by the highest levels of pollution produced indiscriminately by enterprises and individuals summed to globalisation questions has been causing by environmental unbalance and brand-new challenges such as covid-19 pandemics. All these factors create imbalanced life conditions pressuring the manufacturing industry to respect the planet boundaries [11], to pay attention to energy consumption, to plan and execute more ethical operations attending global concerns, such as about pollution threats, which calls for a more environmental-friendly production mode between other sustainability challenges [12] [9].

The changes that this revolution is bringing supported by disruptive technologies are among the biggest challenges of this time [13]. The application of these technologies used with fair purposes can help solve cleaner production problems and achieve higher sustainability maturity. Different types of industries are combining technology and sustainability applied to product lifecycle to achieve corporate sustainability and competitiveness [14] [15]. Industry 4.0 presents a significant opportunity to achieve the goals of sustainable manufacturing and achieving the objectives of the circular economy [16].

These elements indicate that there are no more reasons to keep wheeling the same vicious circle of producing for financial purposes only. And it makes clear the demand for a shift in product lifecycles supported by responsible innovation, with technological applications focused on sustainable development and in all stages of Product Lifecycle, not just for profit.

This paper aims to conduct a literature review to map the research landscape in themes related to how to use Fourth Industrial Revolution technologies to promote Sustainable Development promoting inputs for Product Lifecycle Management. The remainder of this paper is structured as follows: In Section 1, the background is presented. Section 2 illustrates the used scientific method. Finally, Section 3 summarizes the conclusions and outlook.

\section{Background}

The Fourth Industrial Revolution characterised in details by Schwab in 2016 [8], indicating that the digital technologies based on computers, software and networks are working in more comprehensive approaches, with more integration, sophistication and 
robustness, which is transforming economy society globally. With the same premise, Industry 4.0 - a term that first appeared in Hannover Fair in 2011 - intends to use digital technologies to create intelligent factories. The convergence of digital information is necessary in order to integrate physical and digital systems to operate globally and flexible. More than achieve disruptive productivity levels, the 4.0 Industry has as goals more intelligent operations and personalisation of products and services. In other words, technologies have to support disruptive innovation for all types of industries, as we have been presenting in the last years [8].

The rise of technologies, sustainability opportunities, cost reduction and user experience, has produced many initiatives to offer incremental or disruptive innovations including collaborating industry-university-government [17] [18]. However, previous studies indicate that disruptive innovation is the opposite of sustaining innovation [6]. While very positive effects are expected, such as new models development and innovations, improvements in quality and productivity, some not desired effects might occur to society in general, such as an increase of inequalities, polarisation of social power and more [8]. This trade-off brings the necessity to introduce sustainable development concepts and practices to balance the adoption technology that seems so urgent in the agendas of Product Lifecycle.

The term sustainability is not a closed concept. It emerged in the public policies context at the end of the $80 \mathrm{~s}$ as "development that meets the needs of the present without compromising the ability of future generations to meet their own need" [19]. Since then, its concepts have encompassed more application areas extending its meaning for areas not initially planned [20][21]. Therefore, the concepts have been unfolding to corporative environments, bringing out its benefits and shaping new fields of study and applications. The organisational definitions of sustainability in the engineering literature have been more encompassing and have explicitly incorporated the macro view of social, environmental, and economic dimensions by defining organisational sustainability [22].

In a precise definition, Product Lifecycle Management (PLM) [23] is the commercial activity of managing the products of a company throughout its lifecycle, from the first idea of a product until it is removed and discarded most effectively. Further, Product Lifecycle Management may mean a technological solution that encompasses different and complementary tools to promote collaboration between stakeholders to support the Product Lifecycle's effective management [24]. Although Product Life Cycle Management concepts are more commonly found in traditional manufacturing companies, their concepts can also be found in other business profiles such as startups [25].

It seems that these three approaches brought lots of advantages and some disadvantages. However, it seems that the overlap, or a more comprehensive integration of the Fourth Industrial Revolution, Sustainable Development to Product Lifecycle Management, may promote innovation, more robust outcomes in a long-term business perspective.

\section{Method}

\subsection{Systematic Literature Review}

\subsubsection{Search phase and criteria of selection}

This paper aims to identify the state of the art of the thematics that direct this research which main themes are: "Fourth Industrial Revolution", "Product Lifecycle 
Management", and "Sustainable Development". A systematic literature review (SLR) was conducted to achieve the identification of so-called knowledge boundaries. The SLR method was chosen because of its concept of a systematic, explicit and reproducible method for identifying, evaluating and synthesizing the existing body of completed and published work produced by researchers, academics and professionals [26] and [27].

The method consisted of a structured search of the themes "Fourth Industrial Revolution", "Product Lifecycle Management", and "Sustainable Development", and its synonyms or analogue concepts. All the combinations of the keywords and synonyms resulted in 88 strings for search, performed within of the two more relevant databases: Scopus and Web of Science.

The selected documents are in according to the following steps and their respective criteria to respect the scope of the present research:

a) Step 1: search of keywords; b) Step 2: the selection of articles published in the English Language; c) Step 3: the selection of original articles and exclusion of other types of documents such as conference papers, abstracts, book chapters; d) Step 4: the selection of articles that match three keywords in all fields and the removal of duplicated articles; e) Step 5: preliminary reading: abstract reading to meet the scope; f) Step 6: content analysis of the most relevant articles according to the described criteria above. The Systematic Literature Review sequence method is depicted in the seven steps, as shown in figure 1.

b)

\begin{tabular}{|c|c|c|c|c|c|}
\hline $\begin{array}{c}\text { Step 1 } \\
5580 \\
\text { Found } \\
\text { Documents }\end{array}$ & & $\begin{array}{c}\text { Step 4 } \\
2644 \\
\text { articles from } \\
\text { journals }\end{array}$ & & $\begin{array}{l}\text { Step 5 } \\
131 \\
\text { abstract } \\
\text { reading }\end{array}$ & \\
\hline & $\begin{array}{c}\text { Step 2 } \\
\mathbf{5 3 4 9} \\
\text { Articles in } \\
\text { English }\end{array}$ & & $\begin{array}{c}\text { Step 4 } \\
2644 \\
\text { Three } \\
\text { Keywords } \\
\text { match }\end{array}$ & & $\begin{array}{c}\text { Step 6 } \\
12 \text { articles } \\
\text { for content } \\
\text { analysys }\end{array}$ \\
\hline
\end{tabular}

Figure 1. Systematic Literature Review Method

The first raw search result in 5580 documents. Posteriorly, the articles were rigorously selected to meet the scope of this research. Finally, 12 articles were select for meeting all the criteria to have their content thoroughly analysed as described in the next section.

\subsubsection{Content analysis}

The 12 most relevant articles found in the systematic literature review will be analysed in this section. For this step, the method consists of profoundly reading the articles in order to map all the elements and characteristics related to the themes: Fourth Industrial Revolution", "Product Lifecycle Management", and "Sustainable Development."The table summarises the contribution of the 12 articles for this study. 
Table 1. SLR content analysis.

\begin{tabular}{|c|c|c|c|c|c|c|}
\hline $\begin{array}{l}\text { Authons } \\
\text { and year }\end{array}$ & Contributions & Limitations & Applications & $\stackrel{\mathscr{E}}{\forall}$ & $\sum_{\equiv}$ & के \\
\hline $\begin{array}{l}\text { Lai, Lin \& } \\
\text { Wang }(2015) \\
{[15]}\end{array}$ & $\begin{array}{l}\text { A framework to improve } \\
\text { strategic corporate social } \\
\text { responsibility improving } \\
\text { the innovation capability. }\end{array}$ & $\begin{array}{l}\text { The high-level } \\
\text { framework } \\
\text { suggests detailed } \\
\text { unfolding. }\end{array}$ & $\begin{array}{l}\text { Inputs for improvement of } \\
\text { Organizational Factors, } \\
\text { R\&D Factors, } \\
\text { Environment Factors, and } \\
\text { to intensify collaborations } \\
\text { university-industry. }\end{array}$ & $\sqrt{ }$ & $\sqrt{ }$ & $\sqrt{ }$ \\
\hline $\begin{array}{l}\text { 2. Zhang et. } \\
\text { al (2017) [9] }\end{array}$ & $\begin{array}{l}\text { Big data analytics applied } \\
\text { to PLM to promote } \\
\text { Cleaner Production. }\end{array}$ & $\begin{array}{l}\text { The technology } \\
\text { applied to PLM has } \\
\text { its limitations for } \\
\text { replication. }\end{array}$ & $\begin{array}{l}\text { Analytical architecture } \\
\text { applied for PLM, } \\
\text { considering all } \\
\text { technologies. }\end{array}$ & $\sqrt{ }$ & $\sqrt{ }$ & $\sqrt{ }$ \\
\hline $\begin{array}{l}\text { 3.Bradley et. } \\
\text { al (2018) [5] }\end{array}$ & $\begin{array}{l}\text { Total life cycle cost model } \\
\text { to support decisions in } \\
\text { Circular Economy and } \\
\text { Sustainable Manufacturing } \\
\text { implementations. }\end{array}$ & $\begin{array}{l}\text { The mathematical } \\
\text { approach may limit } \\
\text { the replications. }\end{array}$ & Comprehensive analysis. & $\sqrt{ }$ & $\sqrt{ }$ & $\sqrt{ }$ \\
\hline $\begin{array}{l}\text { 4. Lee et. al } \\
(2018)[6]\end{array}$ & $\begin{array}{l}\text { Brainstorming sessions } \\
\text { with scholars resulting in } \\
\text { an advance template to } \\
\text { answer questions related to } \\
\text { 4th IR, Open Innovation } \\
\text { and Sustainability. }\end{array}$ & $\begin{array}{l}\text { Open innovation as } \\
\text { the primary } \\
\text { approach to solving } \\
\text { the issues detected. }\end{array}$ & $\begin{array}{l}\text { Discussion of a } \\
\text { comprehensive approach } \\
\text { of correlated themes may } \\
\text { support future research of } \\
\text { subtopics. }\end{array}$ & $\sqrt{ }$ & $\sqrt{ }$ & $\sqrt{ }$ \\
\hline $\begin{array}{l}\text { 5. Gu et. al } \\
\text { (2019) [28] }\end{array}$ & $\begin{array}{l}\text { Architecture for extending } \\
\text { producer responsibility in } \\
\text { the } 4 \text { th IR context. }\end{array}$ & $\begin{array}{l}\text { Lack of } \\
\text { information shared } \\
\text { between } \\
\text { stakeholders. }\end{array}$ & $\begin{array}{l}\text { Approach considering } \\
\text { legal requirements, } \\
\text { products lifecycle and } \\
\text { system of industry } 4.0 \text { The } \\
\text { ease of replication. }\end{array}$ & $\sqrt{ }$ & $\sqrt{ }$ & $\sqrt{ }$ \\
\hline $\begin{array}{l}\text { 6. Park, Shin } \\
\text { \& Kim } \\
(2017)[13]\end{array}$ & $\begin{array}{l}\text { Social responsibility } \\
\text { model for evaluation of } \\
\text { corporate social } \\
\text { responsibility in the 4th IR } \\
\text { era. Open quality } \\
\text { approach. }\end{array}$ & $\begin{array}{l}\text { Case of } \\
\text { application. }\end{array}$ & $\begin{array}{l}\text { The evaluation model is } \\
\text { generic and appliable to a } \\
\text { different context. }\end{array}$ & $\sqrt{ }$ & $\sqrt{ }$ & $\sqrt{ }$ \\
\hline $\begin{array}{l}\text { 7. Lekan, et. } \\
\text { al. }(2020) \\
{[14]}\end{array}$ & $\begin{array}{l}\text { Construction technologies } \\
\text { to encourage sustainability } \\
\text { goal } 9 \text { - Industry } \\
\text { innovation and } \\
\text { infrastructure. }\end{array}$ & $\begin{array}{l}\text { Building } \\
\text { constructions and } \\
\text { SDG } 9 .\end{array}$ & $\begin{array}{l}\text { Roadmap for achieving life } \\
\text { cycle sustainability goas } \\
\text { with the support of } 4.0 \\
\text { technologies }\end{array}$ & $\sqrt{ }$ & $\sqrt{ }$ & $\sqrt{ }$ \\
\hline $\begin{array}{l}\text { 8. Silk et. al. } \\
(2020) \text { [29] }\end{array}$ & $\begin{array}{l}\text { Decision support - a } \\
\text { techno-economic } \\
\text { framework to overcome } \\
\text { cleaner production } \\
\text { barriers. }\end{array}$ & $\begin{array}{l}\text { Resource recovery } \\
\text { application and } \\
\text { information flows } \\
\text { between } \\
\text { stakeholders. }\end{array}$ & $\begin{array}{l}\text { Economical approach for } \\
\text { sustainability. }\end{array}$ & $\sqrt{ }$ & $\sqrt{ }$ & $\sqrt{ }$ \\
\hline $\begin{array}{l}\text { 9. Rajput \& } \\
\text { Singh }(2020) \\
{[18]}\end{array}$ & $\begin{array}{l}\text { Industry } 4.0 \text { model for } \\
\text { cleaner production and } \\
\text { circular economy. }\end{array}$ & $\begin{array}{l}\text { The model for } \\
\text { deterministic } \\
\text { demand does not } \\
\text { include the reverse } \\
\text { supply chain. }\end{array}$ & $\begin{array}{l}\text { Productivity and energy } \\
\text { consumption. }\end{array}$ & $\sqrt{ }$ & $\sqrt{ }$ & $\sqrt{ }$ \\
\hline $\begin{array}{l}\text { 10. Bai et. al. } \\
\text { (2020) [1] }\end{array}$ & $\begin{array}{l}\text { Assessment framework for } \\
\text { application and } \\
\text { sustainability implications } \\
\text { based on the Sustainable } \\
\text { Development Goals } \\
\text { (ONU). }\end{array}$ & $\begin{array}{l}\text { The implications of } \\
\text { implementation for } \\
\text { different types of } \\
\text { industry. }\end{array}$ & $\begin{array}{l}\text { Relations between the } \\
\text { SDGs and } 4.0 \\
\text { technologies. }\end{array}$ & $\sqrt{ }$ & $\sqrt{ }$ & $\sqrt{ }$ \\
\hline $\begin{array}{l}\text { 11. Tiwari } \\
\text { and Khan } \\
(2020)[10]\end{array}$ & $\begin{array}{l}\text { Framework for } \\
\text { sustainability and } \\
\text { accounting report in } \\
\text { Industry } 4.0 \text {. }\end{array}$ & $\begin{array}{l}\text { The incipient } \\
\text { maturity of } \\
\text { artificial } \\
\text { intelligence. Small } \\
\text { scale industries. }\end{array}$ & $\begin{array}{l}\text { Three levels of } \\
\text { implementation of } 4.0 \\
\text { Industry. }\end{array}$ & $\sqrt{ }$ & $\sqrt{ }$ & $\sqrt{ }$ \\
\hline $\begin{array}{l}\text { 12. Bag et. } \\
\mathrm{Al}(2021) \\
{[16]}\end{array}$ & $\begin{array}{l}4.0 \text { Industry adoption for } \\
10 \text { Rs in manufacturing to } \\
\text { achieve Sustainable } \\
\text { Development. }\end{array}$ & Generalised results. & $\begin{array}{l}\text { Practical factors to cope } \\
\text { with 4th IR, PLM and } \\
\text { Sustainable Development. }\end{array}$ & $\sqrt{ }$ & $\sqrt{ }$ & $\sqrt{ }$ \\
\hline
\end{tabular}




\subsubsection{Discussion}

The discussion was strutured into 5 basic topics (Organisational models, Goverments, Technologies, Product Life Cycle and Sustainability topics):

\section{a) Organisational models}

To guarantee innovation capabilities, enterprises must maintain good strategies for standard domains such as organisational strategy, research and development technology. More than that, it is necessary to complement many critical factors, such as uncertainty and stakeholders in the environment [15]. For some authors [14], these factors are often the catalyst that accelerates organisation and systems development. In this context, the catalyst could be classified as a factor that influences success, often described as critical success factors, [14] that are well described in different approaches in these 12 articles studied. Given that, according to some studies, innovation and sustainability are straight connected. Furthermore, innovation capability directly influences the enterprise capability to implement or improve sustainability [15].

On the other hand, to deal with sustainability in the context of industry 4.0, some authors discuss complementary approaches to organisational models. Transitions from organised economy to entrepreneurship and innovation orientation, economic policies, emphasis on open-design are profiles that may replace traditional economies enterprises. Moreover, businesses should be more creative and resilient to cope with uncertain scenarios. There is a massive growing need for creative solutions to apply for technologies development and specially focused on improving products and services that facilitate the consumers' routines [12].

Nevertheless, more than list the factors, the authors Park et al. suggest an assessment tool for effective enterprise planning and execution of 4.0 Industry and sustainability strategies for product lifecycle. Firstly, the most important factors to be evaluated are leadership and strategic planning from the direction's perspective. Secondly, the authors [13] proposed two categories of systems to be observed: a) Sustainability aspects based on ISO 26000, such as organisational governance, human rights, labour practices, the environment, fair operations practices, consumer issues, community engagement. Moreover, still complementing the systems category, but now aligned with the 4th Industrial revolution, the elements to be evaluated are management quality and responsibility, social value operation, corporate social value, and open data/open quality management. Further, the evaluation process closes with the last block of elements: performance results, financial results, significant process, and customer satisfaction results [13].

Other paper studied proposes a systematic computer-aided framework that evaluates the techno-economic aspects and the environmental potential of a specific initiative such as resource recovery initiatives. According to the authors [30], it is necessary to obtain a good quality of information flows between different stakeholders, such as industrial, society and policymakers. Based on this information, the framework supports an evaluation that may assist overcome the barrier of multidimensional problems and provide solutions and justifying choices in technology readiness, economics, and sustainability [30].

With the understanding of the complexity of digital transformation when overlapped with sustainable productions transition, some authors believe in using frameworks to contemplate all information necessary to make decisions in different stages of implementation or improvement. Additionally to the framework, the techno-economic and sustainability model may maximise the evaluations and decision support addressing 
the circular economy's implementation challenges, resource recovery, and waste management properly [30].

While this last presented framework is based [30] in sustainability and digital transformation goals that match from inside industry to outside, other work seeks to create strategies to match broad external goas as stated by Sustainable Development Goals - United Nations Organisation considering global industry influences in sustainability in supply chains, products and process [1]. The adoption of 4.0 Industry technologies might well not be uniform by industries, and each enterprise needs to choose its best path to achieve sustainability goals (social, environmental and economic). However, a framework can support the decision in different stages: a) evaluating 4.0 technologies for implementation, assisting practitioners, and helping technology roadmaps development [1].

Another proposal of framework encompasses the characteristics of two different theories of operations management: Practice-Based View (PBV) and Dynamic Capability View and considers how technologies of the 4th Industrial Revolution may support the implementation of 10 R's (Refuse, Rethink, Reduce, Reuse, Repair, Refurbish, Remanufacture, Repurpose, Recycle and Recover) [14]. Finally, the success in an endeavour might be achieved by respecting a sequence of factors: 1st) The Establishment of the disruption need; 2nd) The localisation of areas where disruption is needed; 3rd) Rightly instituting methodology to use for the adoption and identification of the possible constraints and barriers; 4th) Personnel training and retraining; 5th) The Set-up of reasonable remuneration and reward mechanism; 6th) The Effective monitoring and control system, and the consolidation of progress achieved and forecast towards enhanced performance [14].

New combinations of business models and cooperation between established firms and startups emerge [12]. The importance of Product-Service System solutions as wellintegrated business models and the convergence between the real and virtual world is growing up.

The use of 4.0 technology with sustainability purpose may bring clear economic and environmental benefits [9], but not only. Another possible approach it conduces changes in product line through corporate responsibility innovation to aggregate benefits immediately realised by consumers. Pay attention to the demands of altruistic consumers may lead to significative changes to the product line. This group of consumers have been pushing companies to act more engaged in sustainability purposes [3].

\section{b) Governments}

As parameters to evaluate the implementation of disruptive technologies in the construction industry can be the economic and commercial impact, the influence of the research on policymakers, and contribution to research knowledge.

More fluidity to capital, collective initiatives to fund projects, the extension of the entrepreneurial role to governments, once their policies are crucial to induce ecoinnovation systems and effective industrial clusters in response to the 4th Industrial Revolution [12]. The government role is to use the technologies with combined strategies with the private sector to promote better and online essential education to support the changes. More overture to co-creation between government and civil society is required to develop more comprehensive solutions - which also includes work closely of universities and firms [12].

Some authors suggest Desing Thinking as an excellent approach to promote effective collaboration and contemplate stakeholders' interests. This methodology would 
help to develop comprehensive solutions based on human needs according to their role in society: government, citizen, university, firm [12].

\section{c) Technologies}

From the perspective of technology implementation, the approximation between stakeholders is crucial to pursue innovation and to discuss large technical development projects actively [12]. When considered threats derived from climate change, new technologies implementation approaches need to consider their impact on sustainability's transformation process. Achieving this innovation with privileges sustainability required all stakeholders' active participation to more transparency in all stages [12].

The consense of the convergence of technologies to promote comprehensive solutions is straightforward. Even if the technologies are the same, their application may be diverse, which means that some technologies may present different maturity levels for some areas or industry. [29]

It is not the scope of this work list all technologies and its application, but select some concepts and approaches to deal with technology seem more compelling. For example, systems should be flexible - which means focusing without losing flexibility [12].

The durability and customisation of products supported by the service-driven and big data-based manufacturing mode, for example, may increase the product lifetime, reduce the amount of the product in circulation in combination with maintenance and refurbishment operations. Further, the technologies allow the identification of new markets and the product will be more competitive in the market and more profitability for the enterprises who adopt this type of technology approach [9].

\section{d) Product Lifecycle}

Product lifecycle data consists of structured, semi-structured and unstructured data. However, several non-real-time data is stored to provide reliable and complete raw data support on further data analysis [9]. Additionally, while there are various set of philosophies and tools that may support the manufacturing to a sustainability transition, some industrial environments factors as process complexity and process uncertainty are more critical, demanding advanced production management paradigms [9], which may work in consonance with technologies and have some alignments with sustainability strategies such as cleaner production or corporate social responsibility.

Still considering the product lifecycle perspective, the economic model may support sustainable manufacturing and circular economy vision. One of the works demonstrated that implemented in the early stages would provide information to support decisionmaking.

On the other side, better experience implementing Extended Producer Responsibility (EPR) Programs with support Industry 4.0 in Product Lifecycles may be found to support the integrated architecture with specific attention on promoting information sharing. Information asymmetry may represent a significant barrier to implementing EPR. However, the comprehensive approach may reshape the industry's paradigms - at least as shown in the case of the electrical and electronic equipment. [28]

About the primary objective, the definitions, applications and potential impacts of Industry 4.0 are introduced as the starting point of this work. Industry 4.0 reshapes the EEE industry's paradigms, as intelligent factories have been set up, and it also offers new opportunities for product development and EPR implementation [28]. 


\section{e) Sustainability Topics}

The authors of the studied works agree that sustainability is a crucial factor for innovation, competitiveness and survival in these uncertain times. However, there are many barriers to integrating technologies, which have their implementation challenges when considered isolated.

Lack of information and knowledge about technologies and sustainability, availability of appropriated equipment, human resources engagement and lack of skills are some of the main challenges faced by PLM for Sustainability adopters [9].

Despite the potential economic and environmental benefits that Cleaner Production (CP) strategy can provide, the implementation of the $\mathrm{CP}$ program continues to face problems and barriers, for instance, an insufficient supply of equipment and information, lack of information about clean technologies, available procedures, and organisational capabilities, as well as organisational barriers such as resistance to change [29].

Implement or improve isolated one of these strategies: Industry 4.0, PLM or Sustainability configures a big challenge. Moreover, to move in the three goals at the same time seems to be an enormous challenge. However, the 12 texts indicate that there are many possibilities to obtain successful implementation if every enterprise is ready to choose the work method that better fits its profile.

\section{Conclusion}

This article has presented a Product Lifecycle Management and Sustainable Development in the context of Industry 4.0 by a Systematic Literature Review. This study's expected outcome is to find elements that can support the use of 4.0 technologies in Product Lifecycle Management with a strong background in Sustainable Development. As the preliminary mapping of the main thematics and challenges, this research does not intend to cover a complete and deep content analysis that is characteristic of a Systematic Literature Review in this paper. However, the analysis of content, even preliminarily, allowed us to identify the main forces driving the 4th Industrial Revolution to PLM with sustainability purposes.

With a base on the study of the 12 selected articles, it is possible to conclude that there is a great movement of industries and enterprises for Disruptive Innovation, which might be supported by one of two of these strategies: Digital transformation and/or Sustainability Transition. With the continuity the research, the authors will propose a framework for transition of sustainability and digital transformation.

\section{Acknowledgements}

The researchers would like to thank the Pontifical Catholic University of Paraná (PUCPR) - Polytechnic School - Industrial and Systems Engineering Graduate Program (PPGEPS) and Technological Development (CNPq) for the funding and structure of this research.

\section{References}

[1] C. Bai, P. Dallasega, G. Orzes, J. Sarkis. Industry 4.0: technologies assesment: a sustainability perspective. International Journal Of Production Economics. 2020, 229.

[2] M. Ameli, S. Mansour, A. Ahmadi-Javid. A simulation-optimization model for sustainable product design and efficient end-of-life management based on individual producer responsibility. Resources, Conservation and Recycling. 2019, Vol. 140, pp.246-58.

[3] H. Xu, Corporate social responsibility, product innovation, and product line. Nankai Business Review International, 2020, Vol.11(2), pp. 171-90.

[4] L. Hetemaki, M. Hanewinkel, B. Muys, M. Ollikainen, M. Palahí, A. Trasobares. Leading the Way to a European Circular Bioeconomy Strategy. European Forest Institute, 2017, https://efi.int/publicationsbank/leading-way-european-circular-bioeconomy-strategy, accessed July, 32021. 
[5] R. Bradley, IS. Jawahir, F. Badurdeen, K. Rouch. A total life cycle cost model (TLCCM) for the circular economy and its application to post-recovery resource allocation. Resources, Conservation and Recycling. 2018, Vol. 135, pp.141-9.

[6] M.H. Lee, J.H.J. Yun, A. Pyka, D.K. Won. F. Kodama, G. Schiuma, et al. How to respond to the Fourth Industrial Revolution, or the second information technology revolution? Dynamic new combinations between technology, market, and society through open innovation. Journal of Open Innovation: Technology, Market, and Complexity. 2018, Vol. 4(3), 21.

[7] N. Kawai, R. Strange, A. Zucchella. Stakeholder pressures, EMS implementation, and green innovation in MNC overseas subsidiaries. International Business Review, 2018, Vol.27(5), pp. 933-946, https://doi.org/10.1016/j.ibusrev.2018.02.004.

[8] K. Schwab. A quarta revolução industrial. Trad. Daniel Moreira Miranda, Edipro, 2016.

[9] Y. Zhang, S. Ren, Y. Liu, S. Si. A big data analytics architecture for cleaner manufacturing and maintenance processes of complex products. Journal of Cleaner Production. 2017, Vol.142, pp.626-41. Available from: http://dx.doi.org/10.1016/j.jclepro.2016.07.123

[10] K. Tiwari, M.S. Khan. Sustainability accounting and reporting in the industry 4.0. Journal of Cleaner Production. 2020, Vol. 258, Available from: https://doi.org/10.1016/j.jclepro.2020.120783

[11] M.Z. Hauschild, S. Kara, I. Røpke. Absolute sustainability: Challenges to life cycle engineering. CIRP Annals, 2020, Vol. 69(2), pp.533-53.

[12] S. Kim, J. Lee. Accounting treatment of R\&D for environmentally responsible firms: Evidence from south korea. Sustainability (Switzerland). 2020, Vol. 12(8), pp.1-16.

[13] S.H. Park, W.S. Shin, K.J. Kim. Assessing a social responsibility model for sustainable company growth in the Fourth Industrial Revolution. International Journal of Quality and Service Sciences, 2019, Vol. 11(3), pp. 334-45.

[14] A. Lekan, C. Aigbavboa, O. Babatunde, F. Olabosipo, A. Christiana. Disruptive technological innovations in construction field and fourth industrial revolution intervention in the achievement of the sustainable development goal 9. International Journal of Construction Management. 2020, pp.1-12.

[15] W.H. Lai, C.C. Lin, T.C. Wang. Exploring the interoperability of innovation capability and corporate sustainability. Journal of Business Research. 2018, Vol. 5;68(4), pp. 67-71. Available from: http://dx.doi.org/10.1016/j.jbusres.2014.11.043

[16] S. Bag, S. Gupta, Kumar S. Industry 4.0 adoption and 10R advance manufacturing capabilities for sustainable development. International Journal of Production Economics. 2021, 231.

[17] M. M. Oliveira,. B. R. Leite, M. Rudek, O. Canciglieri Junior,. Evaluation of the Impact of Open Innovation and Acceleration Programs on Research and Development Performed by Universities. Advances in Transdisciplinary Engineering, 2020. Vol. 14, pp. 92 - 101, DOI 10.3233/ATDE200065.

[18] S. Rajput, S.P. Singh. Industry 4.0 Model for circular economy and cleaner production. Journal of Cleaner Production. Vol. 277, 2020. Available from: https://doi.org/10.1016/j.jclepro.2020.123853

[19] World Commission on Environment and Development (WCED). Our Common Future. Oxford University Press, New York. 1987.

[20] T. Kuhlman, J. Farrington. What is Sustainability? Sustainability. 2010, Vol.2(11), pp. 3436-48. Available from: http://www.mdpi.com/2071-1050/2/11/3436

[21] P. Glavič, R. Lukman. Review of sustainability terms and their definitions. Journal of Cleaner Production. 2007, Vol.15(18), pp.1875-85.

[22] C.R. Carter,. and D.S. Rogers. A framework of sustainable supply chain management: moving toward new theory. International Journal of Physical Distribution \& Logistics Management, 2008, Vol. 38(5), pp. 360-387.

[23] J. Stark, Product lifecycle management. vol.1, pp.1-29. Springer, Cham, 2015.

[24] F. Ameri, D. Dutta. Product lifecycle management: closing the knowledge loops. Computer-Aided Design and Applications. 2005 Jan 1;2(5), pp. 577-90.

[25] B. R, Leite. M. M. Oliveira, M. Rudek, Szejka, A, O. C. Junior, Startup Definition Proposal Using Product Lifecycle Management. Product Lifecycle Management Enabling Smart X, Springer, Cham. 2020, pp. 426-435.

[26] M.F. Muller, F. Esmanioto, N. Huber, E.R Loures, O. Canciglieri. A systematic literature review of interoperability in the green Building Information Modeling lifecycle. Journal of Cleaner Production, 2019, Vol. 223, pp. 397-412.

[27] A. Fink, Conducting research literature reviews: From the internet to paper. Sage, Thousand Oaks, 2019.

[28] F. Gu, J. Guo, P. Hall, X. Gu. An integrated architecture for implementing extended producer responsibility in the context of Industry 4.0. International Journal of Production Research. vol. 57(5), 2019, pp.1458-77.

[29] D. Silk, B. Mazzali, C.L. Gargalo, A.M. Pinelo, I. Udugama, S.S. Mansouri. A decision-support framework for techno-economic-sustainability assessment of resource recovery alternatives. Journal of Cleaner Production, 2020, Vol. 266, 121854.

[30] M. M. Oliveira B. R. Leite, O. Canciglieri Junior. Universities Best Practices in Open Innovation and R\&D. International Conference on Production Research, 2020, Bahía Blanca, Argentina. 